Session 2793

\title{
Growing the Pool of Engineers: Experiences in Hand-On Learning at a Summer Engineering Academy
}

\author{
William E. Pierson, Betsy Dulin, Michael Robinson \\ College of Information Technology and Engineering \\ Marshall University
}

\begin{abstract}
During the summer of 2001, Marshall University hosted the first annual Exploring Engineering: Academy of Excellence. The Academy hosted 29 high school students from the tri-state region of West Virginia, Kentucky, and Ohio who demonstrated an interest in and promise for careers in engineering. The event was sponsored by Marshall University in cooperation with the Huntington Post of the Society of American Military Engineers and Learning for Life. The academy was fully funded by contributions from local engineering firms and industries and a grant from the Nick J. Rahall Appalachian Transportation Institute.

The objective of the Academy was to promote interest in an engineering career by allowing participants to explore opportunities in engineering. Under the supervision of professional engineers and engineering faculty, the participants explored engineering as a career by engaging in hands-on engineering activities, touring engineering facilities, and interacting with engineers and students from all major engineering disciplines, including civil, chemical, electrical, mechanical, and environmental engineering. Activities were designed to promote the importance of problem-solving and team-building skills.

This paper will describe specific activities of the Academy and discuss lessons learned in organizing and conducting the first ever Exploring Engineering: Academy of Excellence. The paper will also discuss student reactions to the Academy and plans for the 2002 event.

\section{Introduction}

Despite the increasing influence of engineering and technology in our lives, interest in pursuing an undergraduate engineering degree has been on the decline since the mid-1980s. ${ }^{1,2}$ Furthermore, when compared to their proportion in the general population, women and minority groups continue to be significantly underrepresented in the engineering profession. ${ }^{3,4}$ While overall enrollment in some technical fields has been driven up by an increase in female student enrollment, fields such as engineering and computer and information sciences have not benefited by an increased interest among women. ${ }^{5}$
\end{abstract}

Proceedings of the 2002 American Society for Engineering Education Annual Conference \& Exposition Copyright (c) 2002, American Society for Engineering Education 
In order to address the problems of declining engineering enrollments, a number of programs have been developed to provide K-12 students an early introduction to engineering with the objective of increasing the level of interest in the profession. ${ }^{6-10}$ As the economy of the state of West Virginia continues to move away from traditional heavy industries such as coal mining and steel production to more technology-based business and industries, the need to promote engineering and science careers among West Virginia students is as great if not greater than at the national level. To help address this need, during the summer of 2001 after nearly a year of planning, fund raising, and preparation, Marshall University in cooperation with the Huntington Post of the Society of American Military Engineers (SAME) and Learning For Life hosted the first annual Exploring Engineering: Academy of Excellence.

The objective of the Academy was to promote interest in an engineering career by providing high school students an opportunity to explore various aspects of the engineering profession. During the weeklong event, these opportunities to explore engineering were presented in several formats:

1. Formal presentations made by practicing engineers,

2. Informal interaction with engineering professionals,

3. Hands-on engineering activities, and

4. Field trips to engineering installations.

As much as possible, all major engineering disciplines were to be highlighted so that a broad range of student interests could be explored. Furthermore, practicing engineers making formal presentations and providing informal interaction with Academy participants would act as positive engineering role models, especially for underrepresented groups such as women. Hands-on activities would be challenging, fun, and provide insights into basic engineering principles. These activities would also require that participants employ effective team skills for successful completion. Field trips to engineering installations would underscore the important contributions that engineers make to our society.

\section{Program Overview}

\section{Planning and Preparation}

While the Academy was held July 8, through July 13, 2001, planning and preparation for the Academy began during the fall of 2000. Six individuals, three Marshall University faculty members and three members of SAME, met regularly to work out details of the Academy. Issues to be resolved included:

1. Identifying a target group of participants;

2. Establishing selection criteria and developing an application form;

3. Designing hands-on activities;

4. Choosing and arranging field trips;

5. Selecting presenters, staff, and engineering representatives;

6. Establishing a schedule;

7. Devising ways to promote and advertise the Academy;

8. Creating a website;

9. Arranging food, lodging, and transportation; 
10. Establishing a set of rules and expectations for Academy participants;

11. Drawing up a budget; and

12. Fund raising.

In order to maximize the immediate benefits to participants, planners decided to target high school students who would be juniors upon returning to school after completing the Academy. Participants must also have demonstrated an aptitude for engineering based upon academic performance, especially in mathematics and science courses, and have a stated interest in engineering. Furthermore, recommendations from school counselors and/or teachers would be required. Based upon available facilities and the projected budget, 30 participants would be invited, and, ideally, these 30 slots would be equally divided between male and female students.

The Academy was promoted by several different means: contacting high school teachers and counselors via direct mail, email, and telephone; newspaper advertisements; and announcements at meetings and events attended by potential students and parents. One such event that was to serve as a sort of kick-off for promoting the Academy was the annual Engineering Career Day sponsored by the Huntington Post of SAME and held during National Engineers Week. Typically, 100 to 120 high school students attend this event, along with teachers, counselors, parents, and corporate sponsors.

Our objective of having an equal number of female and male participants was not met. We found it very difficult to stimulate an interest among female students, and the final pool of accepted students had 21 male and 9 female participants. The total number of applications received was much smaller than anticipated due to several factors, including inclement weather during National Engineers Week and difficulty in publicizing the event through high school teachers and counselors. As a result, there was a wider range of ages than first anticipated. While most participants were rising juniors, there were a few rising seniors and several rising sophomores in attendance, as well. In all, the Academy attendees included students from 18 different high schools and three different states: West Virginia, Ohio, and Kentucky

\section{Budgets}

A decision was made early in the planning process to raise enough money to cover each participant's expenses, with the exception of spending money. It was estimated that approximately $\$ 20,000$ would be required to cover expenses for food, lodging, travel, supplies, salaries, and other miscellaneous items. By fully funding the Academy, no student would be at an economic disadvantage and, therefore, discouraged from applying. We did require that each successful applicant submit $\$ 50$ "earnest money", but these deposits were returned when participants registered on the first day of the Academy.

Fortunately, our requests for support were favorably received from many regional engineering businesses and organizations. A total of $\$ 23,000$ was raised, and fund raising efforts received a significant boost from the Nick J. Rahall Appalachian Transportation Institute (ATI) that provided a grant to match all money raised from corporate sponsors. In addition to its research and economic development initiatives, the ATI is committed to promoting educational outreach efforts in mathematics, science, engineering, and technology. The ATI grant was provided to help fulfill this educational outreach commitment. All sponsors were recognized for there 
support throughout the Academy, with organizational logos appearing on promotional materials and the Academy website.

Detailed expenses for the 2001 Academy were:

- Food and housing - $\$ 9,000$

- Equipment and Transportation - $\$ 7,000$

- Stipends - $\$ 4,000$

口 Prizes, photographs, and miscellaneous items - $\$ 3000$

Schedule, Activities, and Staff

The Academy schedule, shown in section IV of this paper, was designed to intersperse presentations, travel, and hands-on activities. Planners also decided to incorporate very little "down time" in the schedule. This decision was made to maximize the number of engineering experiences received by participants and to minimize the time and opportunity for other, less desirable activities. Generally, each day began with breakfast at 7:00 am and terminated about 9:00 pm, when participants returned to their rooms in a University residence hall.

Hands-on activities were selected that would be fun, stimulating, and that would represent a variety of engineering disciplines. Activities were also chosen to demonstrate the engineering design process and to illustrate the importance of effective team skills in the successful completion of a project. In order to simulate real-world conditions, projects were somewhat open ended, but participants had to deal with the problems presented by constraints of limited time and materials. While Academy staff would be available to provide guidance and technical assistance, participants would be expected to formulate their own solutions to any problems encountered.

Presenters and engineering representatives were chosen to offer a wide variety of perspectives and experiences and act as positive role models for students with varying interests and backgrounds. It has been shown that female students respond positively to women engineer role models, so a conscious effort was made to invite a significant number of women engineering professionals. ${ }^{12}$ Professional engineers who participated in the Academy represented all major engineering disciplines and came from a wide range of business, industry, and governmental organizations. In addition, these individuals were chosen to present a spectrum of engineers at various stages in their careers: from newly graduated engineers to engineers with 25 or more years of experiences; from engineers deeply involved in design to engineers with primarily management responsibilities.

Eight staff members were responsible for daily activities: three members of the Marshall University faculty, three members of the Huntington Post of SAME, a (female) civil engineering graduate student, and a high school teacher. These staff members conducted some of the activities, provided logistical support and technical assistance, helped to promote team skills, and generally acted as mentors and counselors throughout the Academy. Two of the daytime staff members also acted as male chaperones, staying in the residence hall with the participants, and two additional female chaperones were hired to stay with female students during the evening hours. 


\section{Lessons Learned}

From every indication, the Academy was highly successful and fulfilled its primary object: to increase awareness and interest in engineering. Feedback came from informal comments from participants and parents and a survey conducted of the participants. Survey results are shown in section V. The overwhelming success of the Academy was quite gratifying, especially considering that this was the first time the event has ever been held and there were many unknown factors. There were many lessons to be learned, and these lessons are being incorporated into the planning process for EEAE 2002. A summary of things that worked well and things that didn't is provided below.

\section{Things That Worked}

- Hands-on activities, especially the catapult design and build and the Lego robotics project

a Web page (www.marshall.edu/eeae) - nightly updates with pictures of the day's activities was a huge hit with students and parents. The web page has also proved to be a good promotional tool for EEAE 2002.

- Field trip to New River Gorge Bridge

- Team-oriented approach

- Formal interaction with practicing engineers

- Inclusion of parents in opening day presentation and awards luncheon

- Providing big meals and plenty of snacks

a Interaction with practicing engineers during field trips and formal presentations

- Keeping students busy from early morning through the evening hours

- Having a high school teacher and graduate student as counselors

\section{Things That Did Not Work}

口 Any early morning presentation (hands-on activities always worked best for morning sessions.)

- Informal interaction with practicing engineers during luncheons (Students needed some "down-time" after lunch.)

- Not allowing students some extra time to "sleep in" on the final morning

口 Putting students into teams before they warmed up to one another as a group

\section{Tips}

Based upon the results of the survey; feedback from parents, participants, and counselors; and our own experiences from conducting the first Academy, we can offer the following suggestions for anyone who might consider conducting a similar outreach initiative:

口 Do not underestimate the time required for administrative details in registering students and preparing required paperwork. These administrative details required the full-time effort of a secretary for several weeks.

- Students really appreciated the careful attention and planning applied to arranging meals, snacks, and residence hall facilities. Regardless of how well planned and executed engineering activities may be, bad experiences with food or lodging may ruin the overall experience of participants.

- Keep students busy, but be sure to include sufficient time for relaxation. 
- Be flexible and creative. Plan for activities to take longer than expected and for unforeseen technical difficulties to arise.

- Provide and distribute to participants an exhaustive check list of "Things To Bring".

- Place a lot of effort into team building early in the process, and be prepared to mediate the occasional dispute that may arise.

- Institute a dress code, but be reasonable and mindful of current fashions.

- Provide 24-hour contact information for parents.

口 Interact continuously with hosting facility staff prior to and during the event.

- Enlist help of experienced high school students, ideally, previous participants.

- Be proactive and use a variety of techniques to market and promote the event. Don't assume that a simple announcement will generate a sufficient number of responses.

- Math and science teachers seem to be the best source for generating applications. Counselors and principals were less effective.

- Except for supervised field trips, require students to remain within campus boundaries at all times.

- Establish, publish, and enforce a reasonable set of rules, such as room curfews and a "lights-out" policy.

- Maintain separate residence hall floors or areas for male and female students.

\section{Planned Changes for 2002}

As stated earlier, the 2001 Academy was highly successful. By all measures the Academy provided some enriching experiences and valuable insights into the engineering profession for participants. There is no doubt that the effort was worthwhile, and preparations are being made to conduct the 2002 Academy. While everyone was very satisfied with the first Academy, there are a few changes planned for 2002 to make the Academy even more rewarding. The changes planned for 2002 include:

a Minimize the number of formal presentations (lectures). It is expected that there will be only two formal presentations: the opening-day presentation for students and parents and the final day presentation during the awards luncheon.

- Provide a wider variety of engineering experiences during field trips. The trip to the locks and dam will be eliminated and replaced with a visit to a manufacturing or electric generating facility.

- Replace informal interactions with engineers during lunch sessions with a single "What's It Like To Be An Engineer" panel.

- Allow students more down time after lunch and before afternoon activities begin.

- Include more hands-on activities during the environmental sessions.

- Two 2001 participants, one male one female, will be invited to participate as paid counselors.

- Include an opportunity for high school math and science teachers to actively participate in the Academy.

- Develop better pre- and post-survey instruments to better measure the impact of the Academy on the educational plans of participants. 


\section{Academy Schedule}

\begin{tabular}{|c|c|}
\hline \multicolumn{2}{|r|}{ Day 1: Sunday, July 8} \\
\hline $2: 00$ to $3: 00 \mathrm{pm}$ & Registration and Check-In \\
\hline $3: 00-5: 00 \mathrm{pm}$ & Introductions \\
\hline & Presentation: Photonic Polymers \\
\hline & Dr. Heidi Burch, Ph.D., Chemical Engineering \\
\hline & Massachusetts Institute of Technology \\
\hline $5: 00-6: 30 \mathrm{pm}$ & Dinner \\
\hline $6: 30-9: 00 \mathrm{pm}$ & Team building exercises \\
\hline \multicolumn{2}{|r|}{ Day 2: Monday, July 9} \\
\hline 8:00 to $10: 00$ am & $\begin{array}{l}\text { Welcome, Marshall University Administration and Mayor } \\
\text { of Huntington }\end{array}$ \\
\hline 10:00 to Noon & $\begin{array}{l}\text { Presentation: Introduction to Engineering Design and } \\
\text { Catapult Basics }\end{array}$ \\
\hline Noon - 1:00 pm & Lunch With Practicing Engineers \\
\hline $1: 00-4: 30 \mathrm{pm}$ & Teams design and begin catapult construction of \\
\hline $4: 30-5: 30 \mathrm{pm}$ & Dinner \\
\hline $5: 30-7: 30 \mathrm{pm}$ & Complete catapult construction \\
\hline $7: 30-9: 00 \mathrm{pm}$ & Catapult competitions \\
\hline \multicolumn{2}{|r|}{ Day 3: Tuesday, July 9} \\
\hline 8:00 to $10: 00$ am & Travel to New River Gorge Bridge \\
\hline 10:00 - noon & $\begin{array}{l}\text { Presentation: The Principles and Processes of Bridge } \\
\text { Inspections }\end{array}$ \\
\hline Noon - 12:00 pm & $\begin{array}{l}\text { Lunch } \\
\text { Len }\end{array}$ \\
\hline $12: 30-1: 30 \mathrm{pm}$ & Travel to Bluestone Dam \\
\hline $1: 30-3: 30 \mathrm{pm}$ & $\begin{array}{l}\text { Presentation: Materials Sampling and Testing } \\
\text { Tour: Bluestone Dam and Construction Projects }\end{array}$ \\
\hline $3: 30-7: 30 \mathrm{pm}$ & Travel, Dinner, and Return to the University \\
\hline $7: 30-9: 00 \mathrm{pm}$ & Rest and Relaxation \\
\hline \multicolumn{2}{|r|}{ Day 4: Wednesday, July 10} \\
\hline $8: 00$ to $11: 00 \mathrm{am}$ & $\begin{array}{l}\text { Tour: Robert C. Byrd Center for Flexible Manufacturing } \\
\text { Presentation: Computer Aided Design and Manufacturing }\end{array}$ \\
\hline 11:00 - noon & Presentation: Introduction to Robotics \\
\hline Noon $-1: 00 \mathrm{pm}$ & Lunch with practicing engineers \\
\hline $1: 00-5: 00 \mathrm{pm}$ & Teams design, construct, and program Lego Robots \\
\hline $5: 00-6: 00 \mathrm{pm}$ & Dinner \\
\hline $6: 00-7: 30 \mathrm{pm}$ & Complete robot construction \\
\hline $7: 30-9: 00 \mathrm{pm}$ & Robot competitions \\
\hline
\end{tabular}




\begin{tabular}{|c|c|}
\hline \multicolumn{2}{|r|}{ Day 5: Thursday, July 11} \\
\hline $8: 00-9: 00 \mathrm{am}$ & Travel to Robert C. Byrd Locks and Dam \\
\hline \multirow[t]{4}{*}{ 9:00 - noon } & Tour: RCB Locks and Dam \\
\hline & View and discuss construction projects with USACE \\
\hline & Engineers \\
\hline & Presentation: Principles of Water Quality Analysis \\
\hline Noon - 1:00 pm & Lunch \\
\hline \multirow[t]{3}{*}{$1: 00-4: 00 \mathrm{pm}$} & Tour: RCB Locks and Dam \\
\hline & $\begin{array}{l}\text { View and discuss construction projects with USACE } \\
\text { Engineers }\end{array}$ \\
\hline & Presentation: Principles of Water Quality Analysis \\
\hline $4: 00-5: 00 \mathrm{pm}$ & Return to University \\
\hline \multirow[t]{2}{*}{$6: 00-9: 00 \mathrm{pm}$} & Dinner - Pizza Party \\
\hline & Fun and games MU Student Center \\
\hline \multicolumn{2}{|r|}{ Day 6: Friday, July 12} \\
\hline $8: 00$ to $10: 30 \mathrm{am}$ & $\begin{array}{l}\text { Presentation: Studying Engineering in College - } \\
\text { Expectations, Preparations, and Tips for Success } \\
\text { Presentation: Civil Engineering Student Activities at WVU- } \\
\text { Tech }\end{array}$ \\
\hline \multirow{3}{*}{$\begin{array}{l}\text { 10:30 - 11:30 am } \\
11: 30-1: 00 \mathrm{pm}\end{array}$} & Return to room to pack \\
\hline & Awards Luncheon \\
\hline & Keynote Speaker: Provost of Marshall University \\
\hline
\end{tabular}

V. Student Survey Results

How students learned about the Academy.

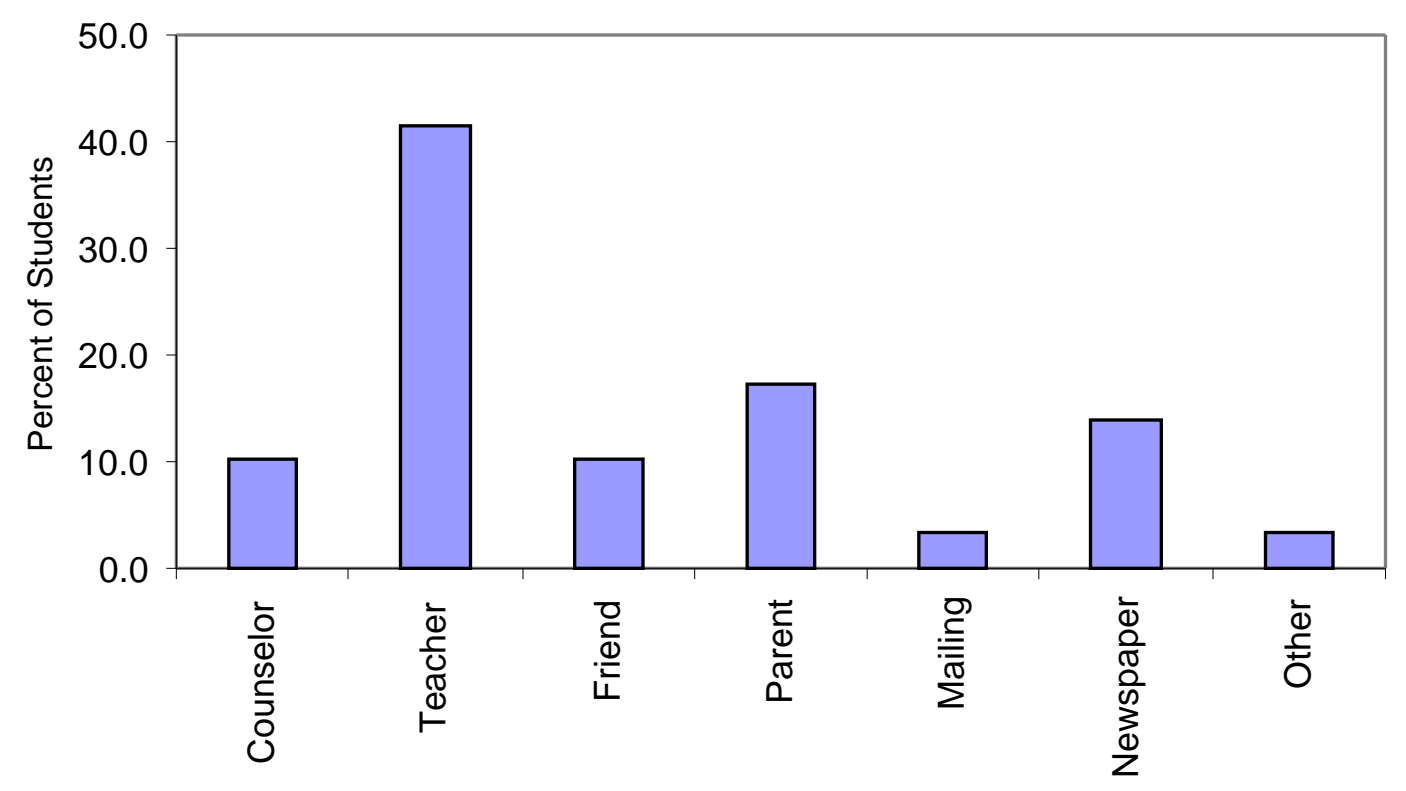

Proceedings of the 2002 American Society for Engineering Education Annual Conference \& Exposition Copyright $($ C 2002, American Society for Engineering Education 
Impact of Academy on student's knowledge of engineering and intent to major in engineering.

Scale: 1 (lowest score) to 5 (highest score)

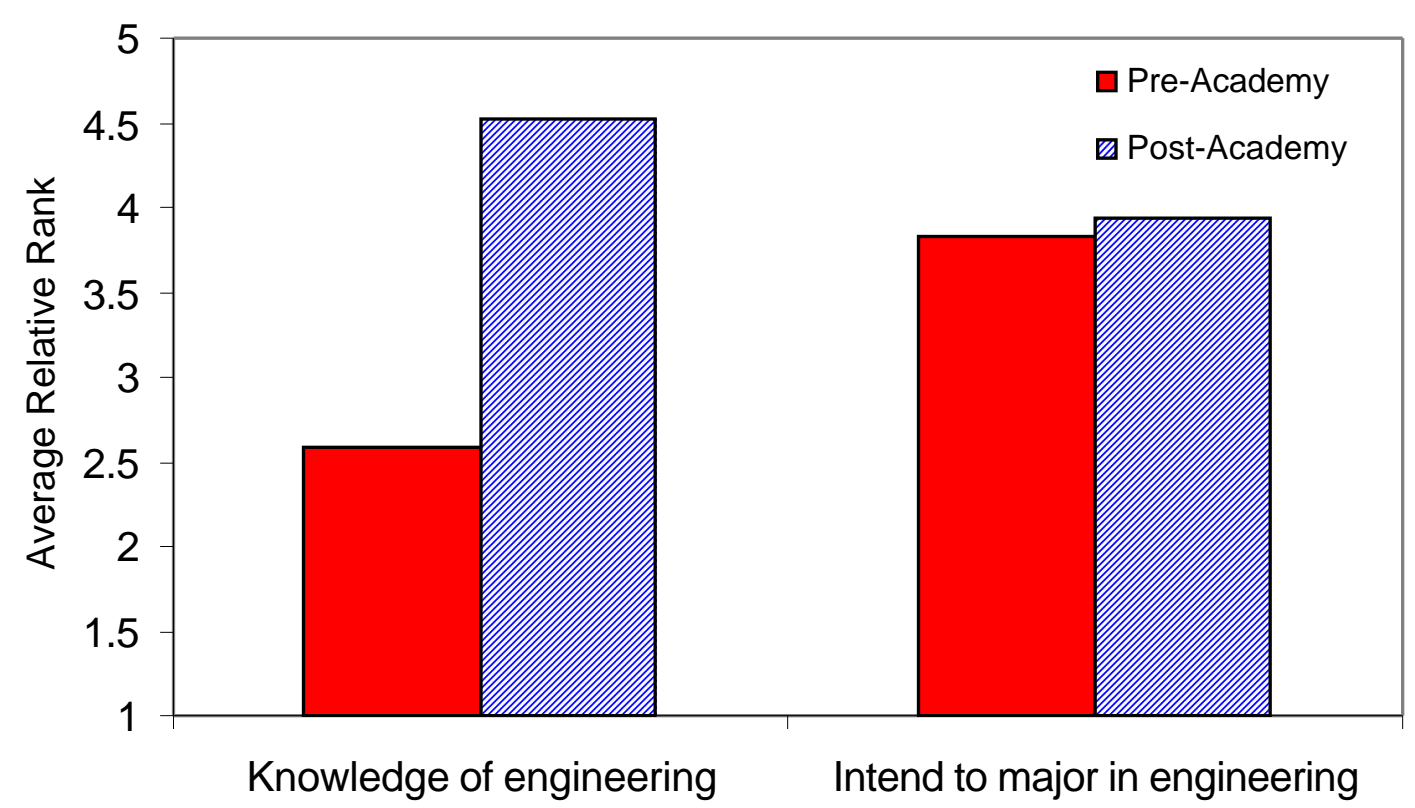

Student enjoyment of the organized group activities

Scale: 1 (least favorite activity) to 8 (favorite activity)

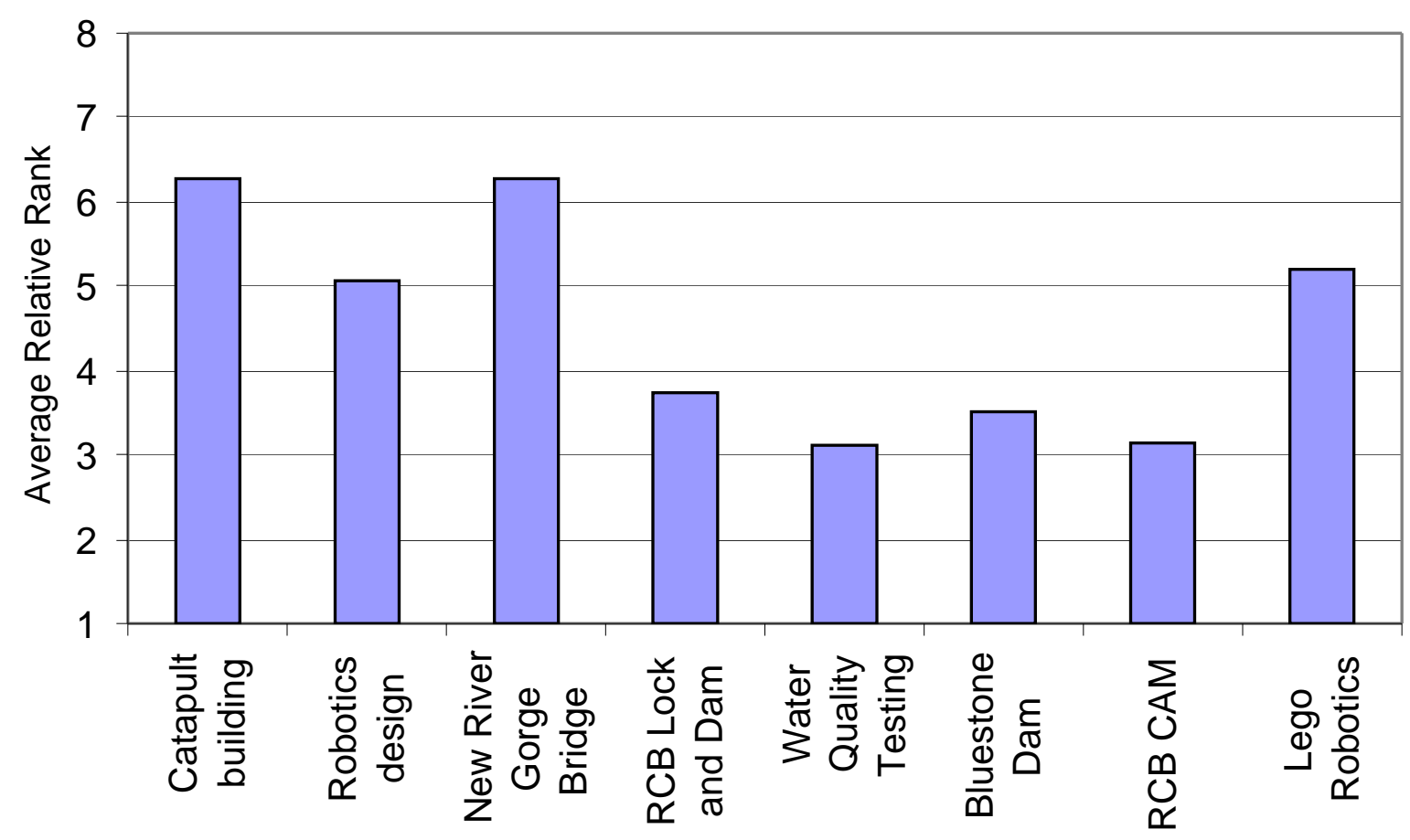

Proceedings of the 2002 American Society for Engineering Education Annual Conference \& Exposition Copyright (c) 2002, American Society for Engineering Education 
Student enjoyment of the organized group activities by Gender

Scale: 1 (least favorite activity) to 8 (favorite activity)

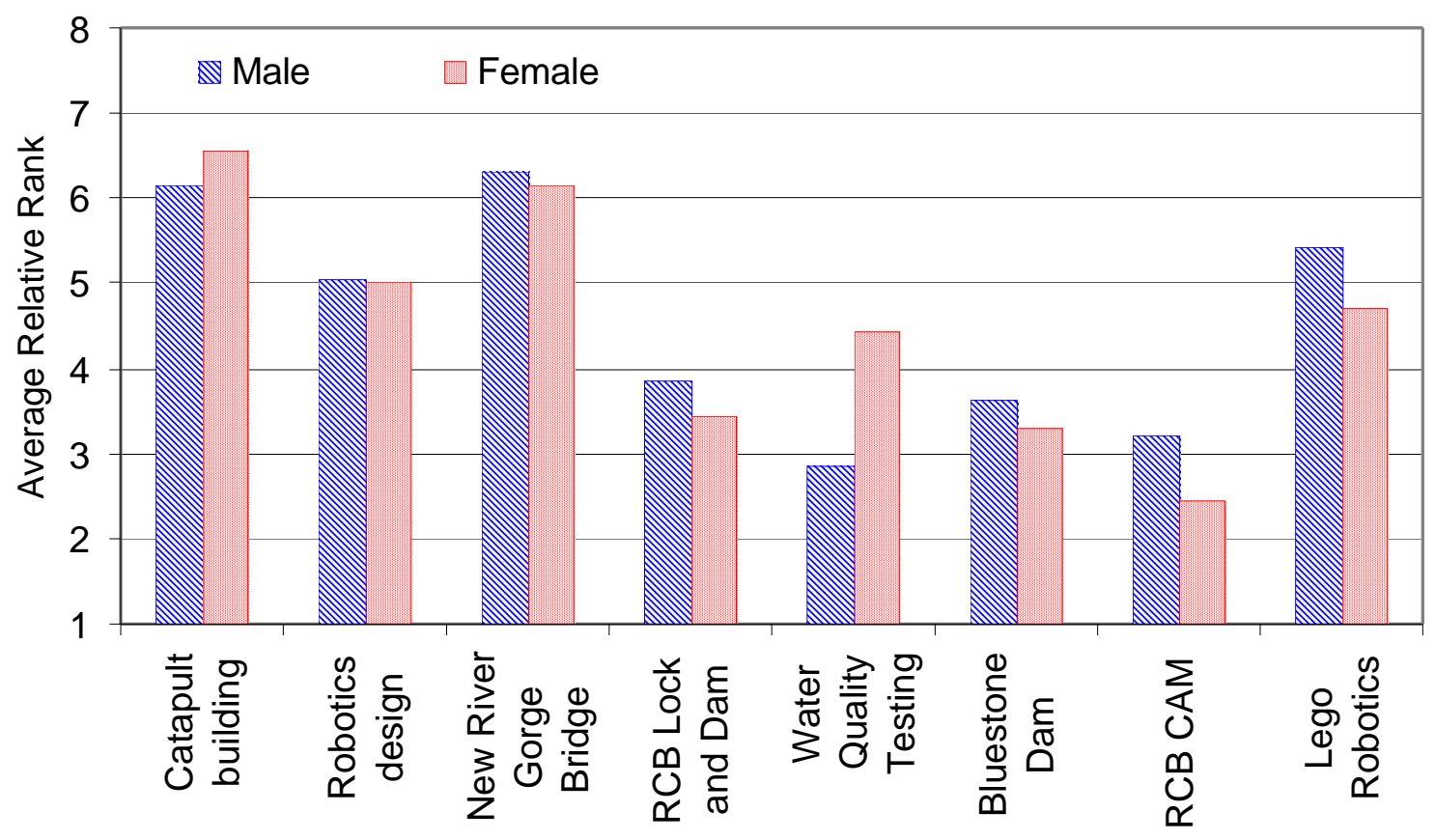

Student responses to assorted questions.

Scale: 1 (least favorable) to 5 (most favorable)

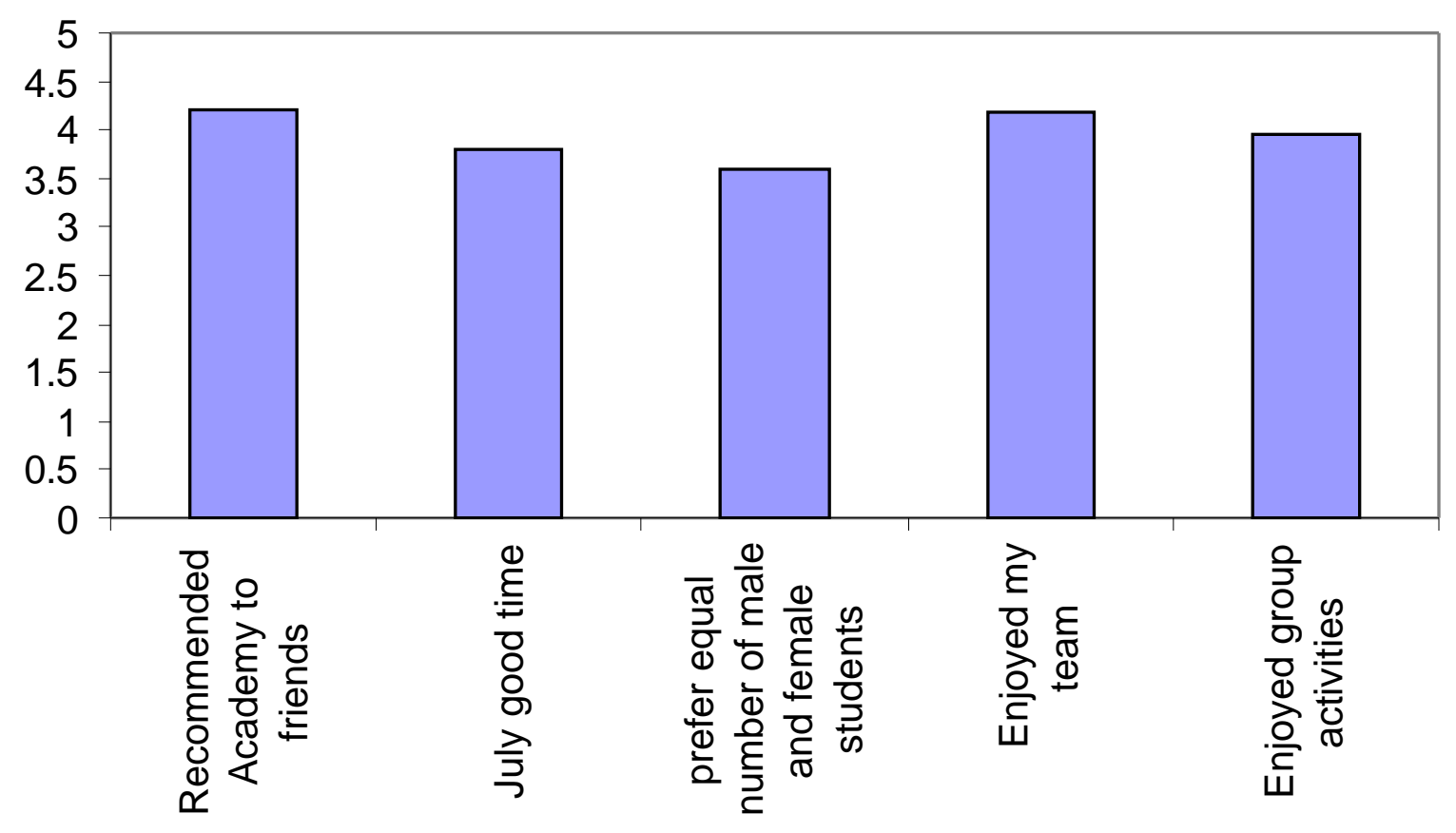

Proceedings of the 2002 American Society for Engineering Education Annual Conference \& Exposition Copyright $\odot$ 2002, American Society for Engineering Education 
Knowledge gained about engineering from various activities.

Scale 1 (did not learn anything) to 3 (learned a great deal)

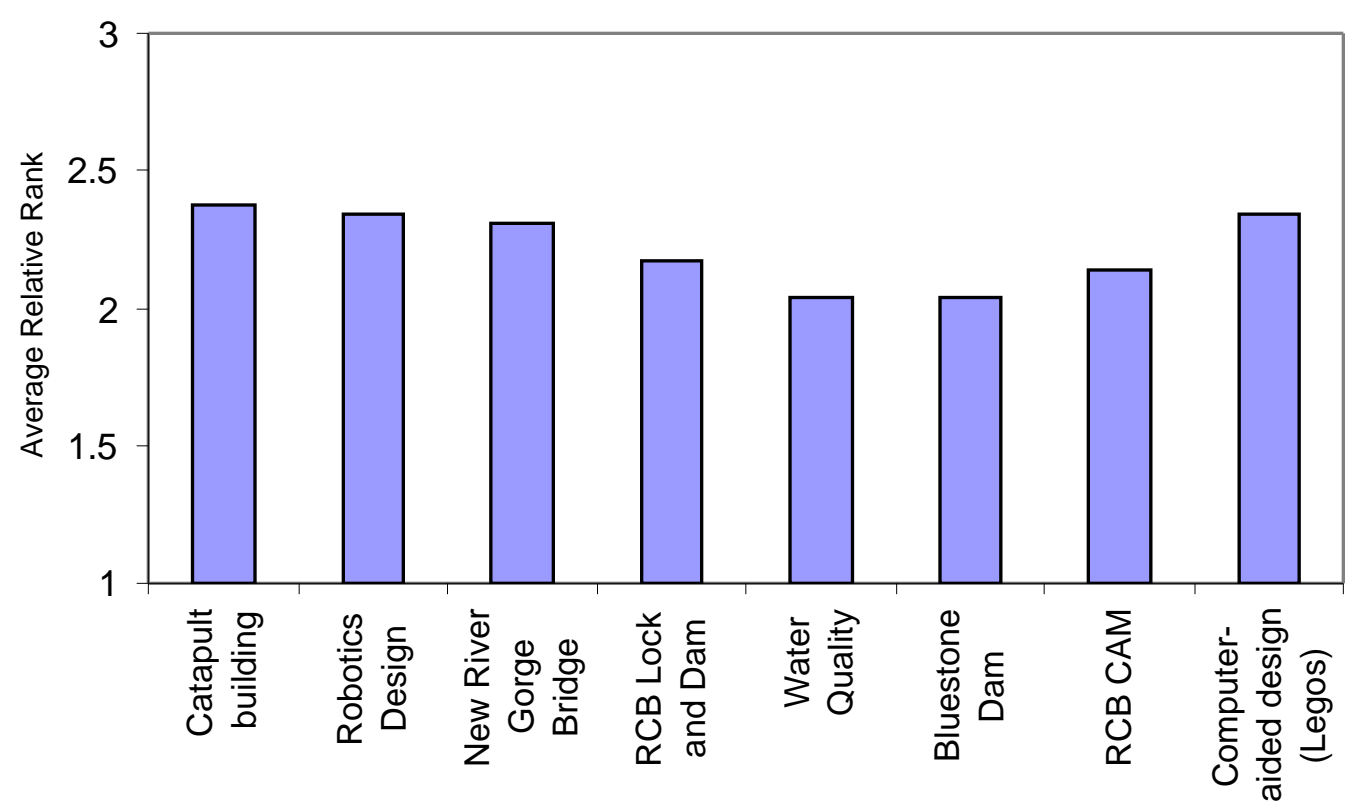

Evaluation of guest speakers.

Scale: 1 (least favorable response) to 5 (most favorable response)

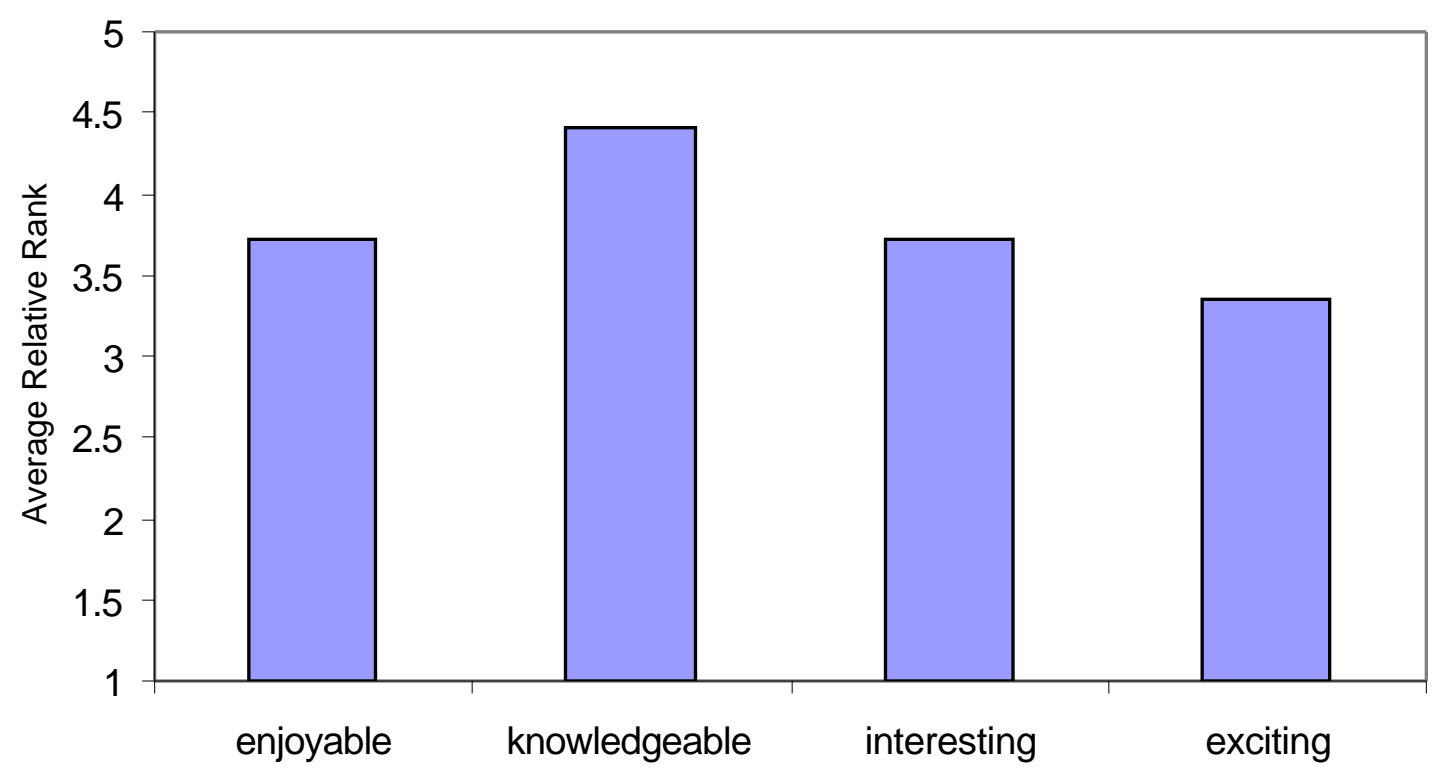


Evaluation of visiting engineers.

Scale: 1(least favorable response) to 5 (most favorable response)

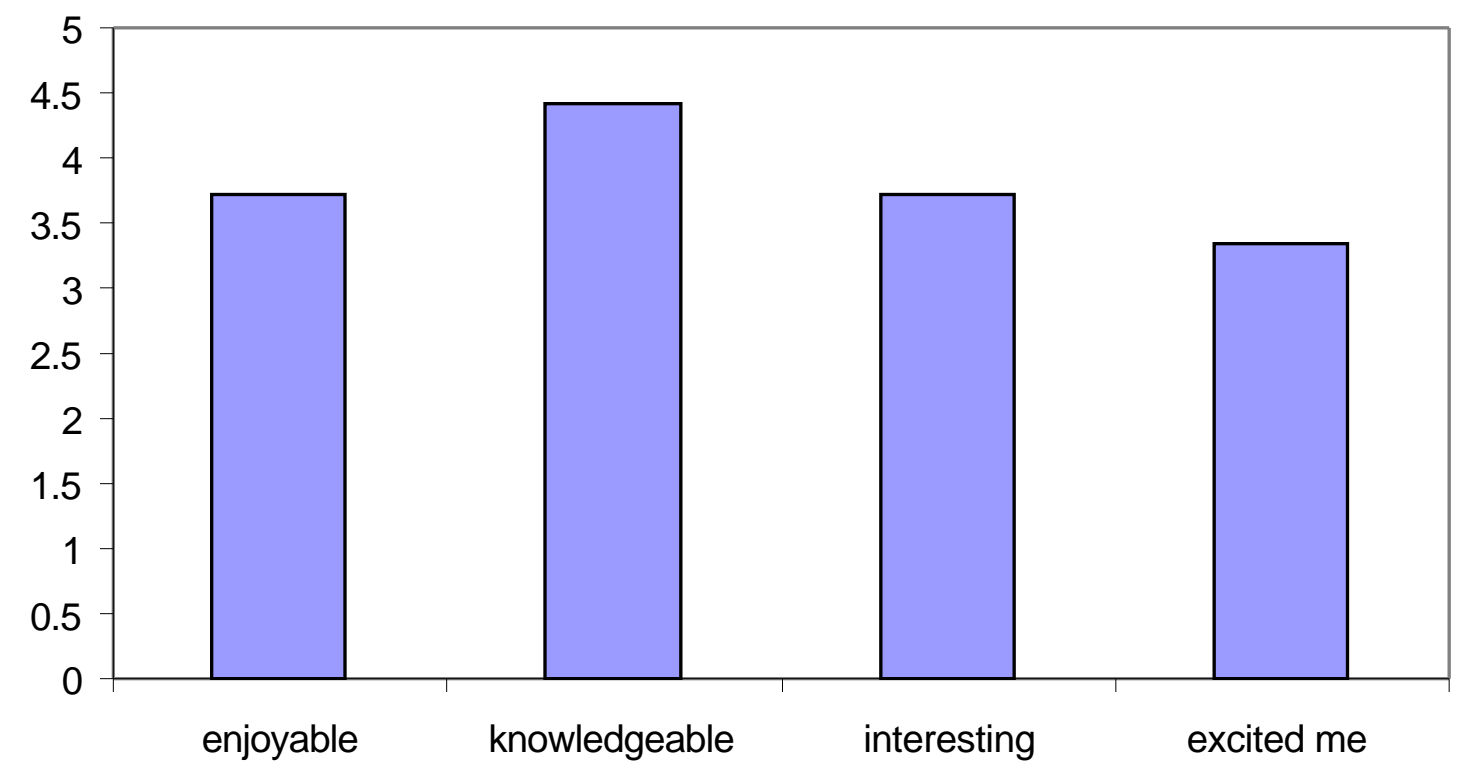

VI. Conclusions

No single outreach effort can generate the desired increase in interest for careers in engineering. To have the greatest impact, outreach efforts must be ongoing, have an influence as early as possible in a student's educational process, and include a spectrum of initiatives tailored to the interests and abilities of various student groups. These efforts must also involve parents and be seen as partnerships between higher education and public schools. The 2001 Exploring Engineering: Academy of Excellence demonstrated that with careful planning and commitment such outreach efforts can produce positive results and can provide beneficial experiences for participants.

However, the 2001 Academy was just the beginning of a partnership between Marshall University, regional engineering societies and businesses, and public school systems to promote and stimulate interest in engineering. Using the lessons learned from the 2001 Academy, we will not only expand and improve the 2002 Academy, we will explore opportunities to launch new initiatives that will target a wider range of students and be tailored to promote engineering to underrepresented groups such as women and minorities. These outreach efforts are essential to growing the size and diversity of the pool of engineering professionals. Furthermore, increasing the number and diversity of engineering graduates is one key element in improving the economic vitality of the region served by the university. 


\section{References}

1. Smith, T.Y., "The Retention and Graduation Rates of 1992-98 Engineering Science, Mathematics, Engineering and Technology Majors in 119 Colleges and Universities," Center for Institutional Data Exchange and Analysis, University of Oklahoma, 1999.

2. U. S. Department of Education, Digest of Education Statistics, 2000, Website URL [http://nces.ed.gov/pubs2001/digest/ch3.html], site visited 1/8/02

3. Mannix, M., "Getting It Right,” Prism, vol. 10, no. 7, Mar., 2001, pp 14-20.

4. Thompson, J., “Engineering Success for Minority Students," Techniques, vol. 76, no. 8, Nov./Dec. 2001, pp 28.

5. Ref. 2

6. Jakubowski, G. S., "Is There a Role for ASEE in K-12 Education," President's Message, Prism, vol. 11, no. 5, Jan., 2002, pp 41.

7. DeGrazia, J. L. et al., “A K-12 University Partnership: Creating Tomorrow's Engineers,” Journal of Engineering Education, vol. 90, no. 4, Oct., 2001, pp 557-563.

8. Creighton, L., “A Pipeline for Young Techies,”, Prism, vol. 10, no. 7, Dec., 2000, pp 37.

9. Kocher, G., "A Really Cool Machine Gives Lessons in Math and Science," Lexington Herald-Leader, Dec. 26, 2001, pp 14-15.

10. The Infinity Project (2001), Technology and Engineering Education for the New Century, Website URL [http://www.infinity-project.org/home.html], site visited 12/5/01.

11. Mathia-Riegel, B., "Engineering That's Elementary," ASEE Prism, March, 2001, vol. 10, no. 7, pp 34-36.

12. Ref. 3.

\section{Biographical Information}

WILLIAM E. PIERSON is a Professor of Engineering and Coordinator of the Pre-engineering Program at Marshall University. He is a licensed professional engineer and received his BSEE from West Virginia Institute of Technology, MSEE from West Virginia University, and Ph.D. in Electrical Engineering from the University of Missouri-Rolla.

BETSY DULIN is Associate Dean and Engineering Division Chair of Marshall University's College of Information Technology and Engineering. She has degrees in civil engineering, environmental engineering, and law, and is a registered professional engineer and attorney.

MICHAEL ROBINSON is an Assistant Professor of Engineering at Marshall University and a registered professional engineer. He earned a B.S. in Chemical Engineering from West Virginia Tech and a M.S. and Ph.D. in Environmental Engineering and Civil Engineering respectively from Virginia Tech. Dr. Robinson's research interests are in the areas of ground water / surface water interactions and engineering education. 